\title{
THE MEDIATING ROLE OF PERSON ORGANIZATION FIT ON THE EFFECT OF ORGANIZATIONAL JUSTICE ON WORK ALIENATION*
}

\author{
Prof. Adnan CCELIKK \\ Selcuk University, FEAS, (acelik@selcuk.edu.tr) \\ Res. Asst. Arif DAMAR \\ Bilecik Seyh Edebali University, The School of Applied Science, (arif.damar@bilecik.edu.tr)
}

\begin{abstract}
Notion of justice has been prevalent in all human societies throughout history as a vital part of the communal living that regulates the relationships between individuals, organizations and communities. As a result of various negative events and unjust policies employees encounter in the workplace, employees can become demotivated and alienated towards their work. Furthermore, employees' fit with the organization and their coworkers decreases. There has been ample research in the literature that studied the relation between organizational justice and work alienation. This study is important in that it investigates the role of the person organization fit's agency (mediating effect) when determining the effects of organizational justice on the levels of work alienation. Population of this research consists of the employees employed in an enterprise located in Konya that is present in energy sector. As a data collection tool surveys were used and 120 valid surveys were obtained. The collected data was evaluated using SPSS 23,0 application. Reliability analyses were performed on the three tests used to measure the organizational justice perception, work alienation level and person organization fit of the employees. An explanatory factor analysis was also performed to determine the aspects of the related concepts. Correlation analyses showed that there is a statistically significant relationship between aspects of organizational justice, work alienation and person organization fit. Additionally regression analyses showed that perception of organizational justice can be used to predict the employees' work alienation level. Same analyses also confirmed the person organization fit on the effects of organizational justice on work alienation.
\end{abstract}

Keywords: Organizational Justice, Work Alienation, Person-Organization Fit

\footnotetext{
${ }^{*}$ This proceeding was presented at International Congress on Management Economics and Business on the 7-9 September in 2017 in Zonguldak-Turkey.
} 


\section{Introduction}

All organizations have rules to regulate personal interactions between employees, determine responsibilities and maintain order. Individuals that obey these rules contribute to the organization in an active and efficient way. Because the employees who fulfill their responsibilities in the organizations, compare the attitudes, attitudes and achievements exhibited in the organization with one another. When employees perceive injustice, they show some negative behavior to turn this situation into their favor. This leads to negligence at work, loss of work discipline and ultimately organizational damage as a result of lowered performance. Thus, perception of injustice in organizations leads to an increase of work alienation in employees.

Work alienation, in general, is defined by reluctance to work, decrease in job satisfaction, a loss of motivation regarding career and overall negative emotions stemming from a feeling of incompatibility with work and organization. Work alienation affects employee efficiency and performance negatively. Thus, managers in organizations seek to keep work alienation at minimum.

Primary aim of this study was to investigate the relationship between organizational justice perception and work alienation. In the study organizational justice has been evaluated in three sub-dimensions named as distributive justice, procedural justice and interactional justice. The contribution of these sub-dimensions to work alienation has been studied.

\section{Theoretical Framework}

\subsection{Organizational Justice}

Justice is defined as "rights, rightfulness and respecting rights" (www.tdk.gov.tr). The concept of organizational justice is a reflection of justice in the workplace (Polatçı ve Özçalık, 2015: 219). Throughout history, the requirements for individuals to live in a community in order to achieve their own goals has resulted in legislative regulations regarding the distribution of resources among individuals and relations between individuals. These legislations were made to enforce justice to keep personal relations between individuals positive (Yürür, 2008: 296). This concept of justice has been also discussed by philosophers. Socrates defined justice as an individual fulfilling his or her responsibility while not interfering with others. In a similar way, the concept of justice was defined by Plato as knowing the responsibilities and doing one's job. According to Aristotle not obeying the law and abusing the law for personal gain was injustice and conversely obeying the law and equality was justice (Topakkaya, 2008: 31-34).

Organizational Justice's foundation lies in Adams' theory of equality (1965) and Crosby's theory of relative deprivation. According to theory of equality an individual's perception of justice in a given organization depends on the ratio of their contribution to the organization (effort, time, cognitive resources etc.) to their personal gain (salary, promotion, self-improvement opportunities etc.). Afterwards they compare this ratio of contributionpersonal gain with the ratios of their peers (Cropanzano ve ark., 2001: 167; Greenberg, 1989: 174). According to the deprivation theory those who rank lower in an organization compare their gains with the gains of other employees. This results in these lower-ranked employees to feel deprived (Cowherd ve Levine, 1992: 304).

Organizational Justice was first used by Greenberg (1987). According to Greenberg (1990), perception of organizational justice was a core requirement for an organization to work efficiently (Polatçı ve Özçalık, 2015: 219). Organizational justice plays an important role in maximizing the human factor as a productive resource because justice, unlike objective or mandatory morals, is an explanatory concept which we personally believe to be true (Cropanzana ve ark., 2007: 35). This suggests that if organizations wish to maintain themselves and profit, they must be careful to pay attention to their employees. Organizations should also work to increase the job commitment and satisfaction of their employees and use every opportunity to do so.

According to Folger ve Cropanzano (1998) organizational justice is the rules and social norms that determine how rewards and punishments are decided and delivered. A low perception of organizational justice increases the employees intention to quit (Ölçer, 2015: 1). An employee's intent to quit the job will cause him to be unable to do his job properly. Hence, the perception that individual interests are damaged will not make any contribution to organizational interests.

In literature, justice consists of three sub-dimensions; distributive justice, procedural justice and interactional justice (Nadiri ve Tanova, 2010: 34). Distributive justice is one of the oldest forms of justice. It is related to the decisions made by the managers in an organization and how these decisions are perceived to be fair. Procedural justice is concerned about how employees participate in the decision making and how this process is perceived to be fair (Moon ve ark., 2008: 85). There are two pre-requisites for this justice. The first one is the personal justice. The decision makers must be respectful and fair in their decisions. The decisions must not hurt the employees and employees must be adequately informed about the decision and the process. The second pre- 
requisite is known as "informational justice" and it requires organization managers informing the employees regularly about decision making process (Altaş ve Çekmecelioğlu, 2015: 424; Colquitt, 2001: 386).

\subsection{Work Alienation}

Work alienation is usually defined by an individual's loss of interest in work, and negative feelings felt by an employee as a result of disappointments regarding work/career and an anxiety due to a failure to adhere to organizational norms (Aiken ve Hage, 1966: 497; Kanten ve Ülker, 2014: 21). There are many definitions regarding "alienation". As a concept "alienation" is marked by an inability to express oneself, lethargy towards work, a feeling of isolation, incompatibility with business values and other events that cause disruptions in consciousness caused by the inability to express oneself (Bonjean ve Grimes, 1970: 366; Taştan ve ark., 2014: 124). The alienation of employee to their work leads to the least effort for the work they do. This situation reduces the organizational commitment of the employees and it can damage the organization.

Alienation, in a philosophical context, was first used by Hegel in his "Phenomelogy of Spirit". An individual's alienation towards environment and self stems from the gap between a human being's physical and spiritual existence (Şirin, 2009: 165). Hegel considers alienation to be a natural phenomenon and not a disease; according to him "as long as nature, human beings and society exists so will the alienation" (Şimşek ve ark., 2006).

Alienation is the transformation of the individual's life to a form that is incompatible with that individual's self and lifestyle. Alienation is usually describes as the transformation of an individual from the subject of life to an object of life (Şimşek ve ark., 2006: 570). The employees who must try to live contrary to their job cause fail to have their responsibilities and lose their compatibility with their job.

\subsection{Person-Organization Fit}

According to TDK, fitting is the harmony between the parts of the whole, adherence to adapt to environment or society or to a given situation (tdk.gov.tr). Generally being fit means that a human being is interacting with his or her inner self and environment in peace (Özçelik, 2011: 38). Person-Organization Fit studies starts with Lewin's (1963) definition of human behavior as a function of the individual and individual's environment. In an organizational context person-organization fit is a process that affects employees attitude and behavior towards work. In a more general sense it is related to how individuals' personal values, beliefs, norms and expectations are compatible with theirs (Polatçı ve Cindiloğlu, 2013: 300).

Person-Organization fit is defined as the compatibility between personal values and organizational values such as being innovative and team-focused (Chatman, 1991: 459). Yahyagil states that person-organization fit is the general harmony between individuals and the values of the organization they work in, compatibility between organizational leaders and the purpose of the organization and the harmony between the general structural systems of the organization and the needs of the employees (Yahyagil, 2005: 138).

\subsection{Organizational Justice, Work Alienation and Person-Organization Fit}

Employees' organizational justice perception is very important for the organizations, because employees may not be able to rationally evaluate whether their superiors have made just decisions about a given situation. Evaluations regarding organizational justice is done personally and easily affected by the emotions of the employees. In these contexts individuals' organizational justice perception will invoke both positive and negative emotions regarding their work. Various negative feelings stemming from this will lead to a decrease in job satisfaction, exhaustion and an increased tendency toward work alienation (Turgut ve Kalafatoğlu, 2016). In a study conducted by Kurtulmus ve Karabiyik (2016) on 302 teachers, it was determined that there was a significant relation between organizational justice perception and work alienation. In a study conducted by İşcan ve Sayin (2010) on 190 employees, it was determined that organizational justice perceptions and job satisfaction had a strong positive effect on organizational trust. In another study by Ceylan ve Sulu (2011) conducted in Istanbul on 377 health-care professionals working in various hospitals, it was determined that there was a significant relationship between dimensions of work alienation and distributive, procedural and interactional justice. A study by Günsal (2010) on 342 bank employees demonstrated a negative correlation between organizational justice and work alienation.

Employees' organizational justice perception affects their compatibility with work and their relationships with their co-workers. This can lead to a decrease in job commitment and satisfaction, lowered motivation and ultimately work alienation. As a solution, managers should focus on qualification from recruitment and evaluate employees solely based on their competence. This in turn will increase the organizational justice perception of the employees, an increased harmony between personal beliefs and norms and in the future an increase in job commitment. 


\section{Research Methodology}

\subsection{Theoretical Model and Hypothesis}

This study is an empirical research. The aim of this study is to answer the question "does the organizational justice perception of the employees affect work alienation levels and person-organization fit?" Managers in the organization should adhere to principles of equity, avoid discrimination among employees and be fair. This will motivate the employees which in turn will lead to an increase in employees' work performance and job satisfaction. Thus, their person-organization fit increases and work alienation levels decrease. In this context, organizational justice influences both employees' alienation level and their harmony with the organization.

\section{Figure 1: Theoretical Model}

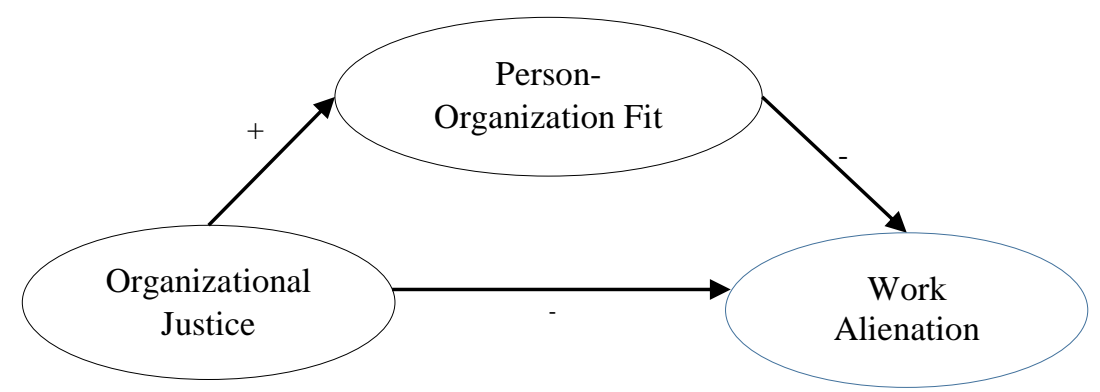

$\mathrm{H}_{1}$ : Organizational justice has a negative effect on work alienation

$\mathrm{H}_{2}$ : Organizational justice has a positive effect on person-organization fit

$\mathrm{H}_{3}$ : There is a mediating role of person-organization fit on the effect of organizational justice perception and work alienation levels.

\subsection{Research Subject, Purpose and Importance of the Study}

Today, enterprises are always trying to increase their competitiveness by protecting their assets and making more profit, more efficiency. However, it is very hard to be successful and to maintain this success in the face of strong competitors. Each section or unit in an enterprise should work together in harmony and it is necessary to establish a fair structure within the organization. Believing that the managers exhibit fair behaviors increases the commitment of employees to work and the satisfaction employee receive from their work. This situation will combine the individual values and organizational values. Thus, work alienation levels will be lowered. This study will investigate in the role person-organization fit in organizational justice's effects on work alienation.

\subsection{Data Collection Tools and Measurement}

Organizational Justice: In order to mesure the organizational Justice the scale developed by Niehoff and Moorman (1993) which was also adapted by Atalay (2007). Organizational justice has three sub-dimensions; distributive justice, procedural justice and interactional justice. The scale consists of 20 items. Items 1-5 measure the distributive justice, 6-12 measure procedural justice and items 12-20 measure interactional justice.

Work Alienation: Work Alienation scale that was developed by Mottaz (1981) measures work alienation and has 21 items in sub-dimensions such as powerlessness, futility and self-alienation. The scale was adapted to Turkish by Erben (2008). However Sayü (2014) revised the scale due to certain items lacking clarity and meaning. As a result, the scale preserved its three-sub dimension structure but was reduced to 17 items. Furthermore, in the original alienation scale all statements and items were asked in positive sentences has been changed into negative. The sub-dimensions were powerlessness, self-alienation and meaningless.

Person-Organization Fit: Person-Organization Fit scale developed by Netemeyer ve ark. (1997) was used. This scale has one-dimensional and is consisted of 4 items. It was adapted to Turkish by Turunç ve Çelik (2012).

A five-point scales that ranges from 1- Strongly disagree to 5-Strongly agree was used and the reliability (cronbach alpha) of it was over 0.85 . In the last part of the questionnaire, there were questions about the sociodemographic characteristics of the participants.

Research has been conducted to a big enterprise in Konya that works in energy sector. Population was comprised the workers employed in this enterprise. Research sample was not limited to a specific group; all employees were included. However due to time constraints only 120 surveys were fully answered and was 
determined to be valid for evaluation. This study is limited in several ways. These were among the scope of the research which was limited to a single enterprise in Konya and the usage of surveys as the only method of data collection. Only employees in the organizations were surveyed under a time constraints which further demonstrates the limited scope of the research.

\section{Results}

\subsection{General Results}

Demographic features of the employees such as gender, marital status, education, age, work experience and status in organization as part of our research was shown in Table 1 below.

Table 1: Demographic Features of the Employees

Demographic Findings $(\mathrm{n}=120)$

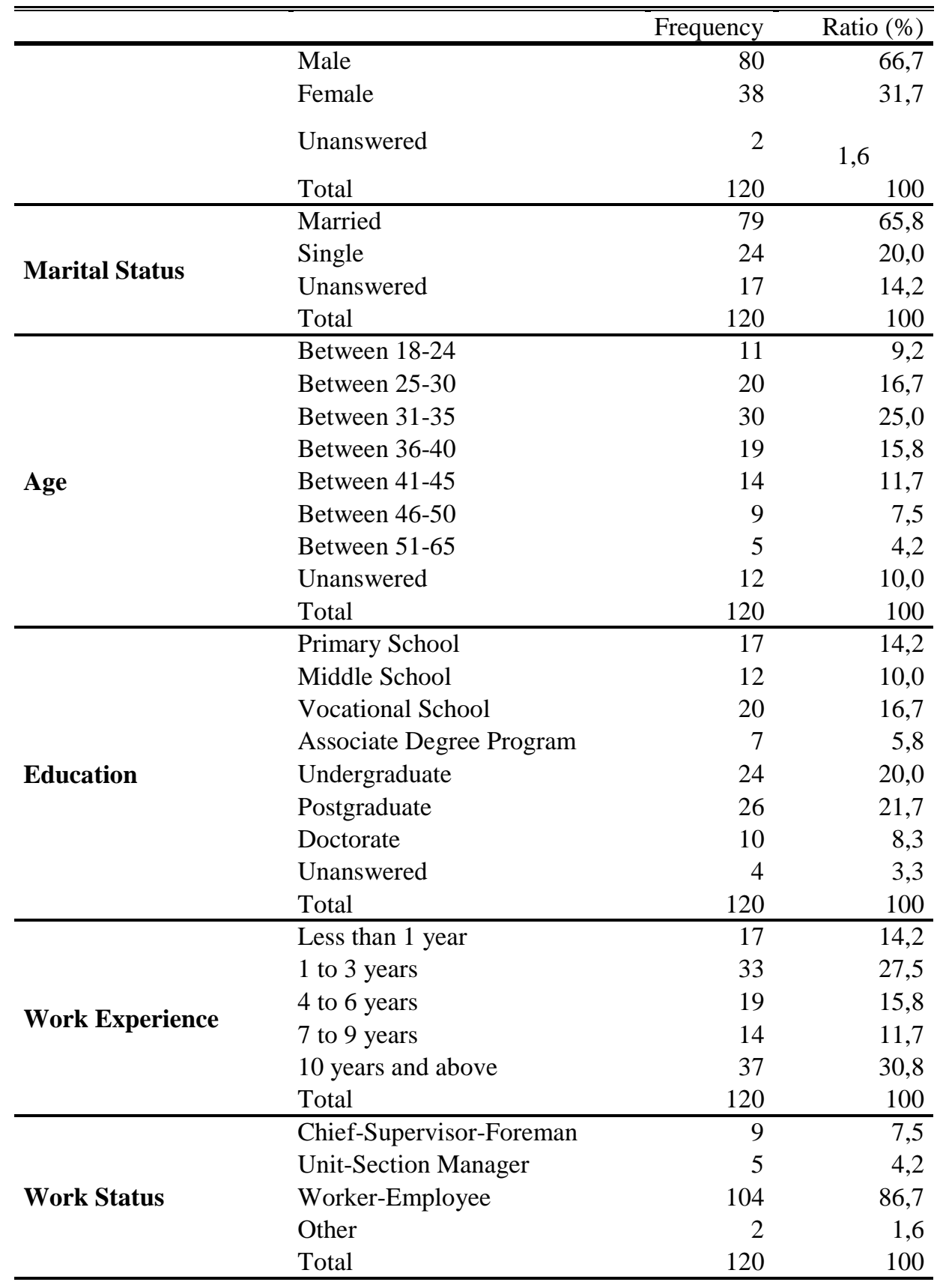

A total of 120 employees participated the study. $66,7 \%$ of them were male, 31,7 were them female. $65,8 \%$ were married, $20 \%$ were single. Research showed that a majority of them, $40,8 \%$ were between 31 to 40 years old. $21,7 \%$ had postgraduate, $20 \%$ had graduate and $8,1 \%$ had doctorate degrees. Also $86,7 \%$ consisted of employees. 


\subsection{Reliability Evaluation of Organizational Justice, Work Alienation and Person-Organization Fit Scales}

A factor analysis has been conducted to determine the sub-dimensions of organizational justice and work alienation. Data set was subjected to Kaiser-Meyer-Olkin (KMO) sample sufficiency test and Bartlett's Test of Sphericity to determine the suitability for factor analyses. KMO value was over 0.50 and Bartlett test's critical tail value was found to be 0.05 which determined data set was suitable for factor analyses.

Table 2: KMO and Reliability Coefficients

\begin{tabular}{|c|c|c|c|}
\hline $\begin{array}{l}\text { KMO } \\
\text { sufficiency }\end{array}$ & $\begin{array}{c}\text { Organizational } \\
\text { Justice }\end{array}$ & $\begin{array}{c}\mathrm{KMO}=0,873 \\
\text { Cronbach Alpha } \\
(\alpha=0,928)\end{array}$ & $\begin{array}{l}\mathrm{X}^{2} \text { Bartlett: } 1181,825 \\
\text { Sd: } 136 \\
\text { Tail Critical Value p: } 0,00\end{array}$ \\
\hline & $\begin{array}{c}\text { Work } \\
\text { Alienation }\end{array}$ & $\begin{array}{c}\mathrm{KMO}=0.780 \\
\text { Cronbach Alpha } \\
(\alpha=0,853)\end{array}$ & $\begin{array}{l}X^{2} \text { Bartlett: } 659,671 \\
\text { Sd: } 120 \\
\text { Tail Critical Value p: } 0,00\end{array}$ \\
\hline & $\begin{array}{l}\text { Person- } \\
\text { Organization } \\
\text { Fit }\end{array}$ & $\begin{array}{c}\mathrm{KMO}=0,824 \\
\text { Cronbach Alpha } \\
(\alpha=0,922)\end{array}$ & $\begin{array}{l}X^{2} \text { Bartlett: } 364,867 \\
\text { Sd: } 6 \\
\text { Tail Critical Value p: } 0,00\end{array}$ \\
\hline
\end{tabular}

demonstrated the homogenous structure of the variables and therefore, their suitability for factor analyses whereas Bartlett test correlation matrices of the variables were significant. Data that was acquired were subjected to factor analysis to determine the sub-dimensions of organizational justice and work alienation. Items were analyzed using principal components and varimax rotation method. Items that had sample sufficiency scores lower than 0,50 , and items that had similar factor weight were removed from the analyses to obtain factors with a core value above 1. Reliability of scales were measured and it was determined orderly that Cronbach Alpha $(\alpha=0,853)$, Cronbach Alpha $(\alpha=0,928)$ and Cronbach Alpha $(\alpha=0,922)$. An EFA analysis was conducted to determine the subdimensions of work alienation. In literature sub-dimensions of work alienation were defined as self-alienation, meaninglessness and powerlessness. However the item “12. Most satisfactory part of my job is my salary.” was removed during reliability analyses.

Table 3: Reliability of Work Alienation Sub-Dimensions

\begin{tabular}{|c|c|c|}
\hline Factor & Item & $\mathrm{p}$ \\
\hline $\begin{array}{l}\text { Self- } \\
\text { Alienation }\end{array}$ & $\begin{array}{l}\text { 4. I can't fulfill my expectations while working. } \\
\text { 5. I am deprived of the opportunity to supervise myself. } \\
\text { 6. I am deprived of the opportunity of choosing my co-workers. } \\
\text { 15.My work feels like a punishment } \\
\text { 16.My job offers very little opportunity for creativity }\end{array}$ & 0,789 \\
\hline $\begin{array}{l}\text { Meaningless } \\
\text { ness }\end{array}$ & $\begin{array}{l}\text { 7.I can't see the role of my organization in my job } \\
\text { 8. There are times that I can't determine the purpose of my work } \\
\text { 9.I don't understand the part of my work in the grand scheme of } \\
\text { things } \\
\text { 10.I don't how my work fits with the work of others } \\
\text { 11. I don't feel accomplished in my job. } \\
\text { 13. My job does not satisfy me. } \\
\text { 14.I have very to little opportunities to use my talents at work } \\
\text { 17.My job requires very little effort }\end{array}$ & 0,843 \\
\hline $\begin{array}{l}\text { Powerlessnes } \\
\text { s }\end{array}$ & $\begin{array}{l}\text { 1. I can't make work related decisions without my superiors. } \\
\text { 2. I have no opportunity to change my work environment. } \\
\text { 3. My work in the work place is mostly determined by others. }\end{array}$ & 0,674 \\
\hline
\end{tabular}


Table 5: Reliability Value Regarding Person-Organization Fit

\begin{tabular}{|c|c|c|}
\hline Factor & Item & $\mathrm{p}$ \\
\hline $\begin{array}{l}\text { Person- } \\
\text { Organiza } \\
\text { tion Fit }\end{array}$ & $\begin{array}{l}\text { 1. My personal values are a good fit for my organization. } \\
\text { 2. Values of the organization I work for are in line with my } \\
\text { personal values regarding other people. } \\
\text { 3. Values of the organization I work for are in line with my } \\
\text { personal values regarding honesty. } \\
\text { 4. Values of the organization I work for are in line with my } \\
\text { personal values regarding fairness. }\end{array}$ & 0,922 \\
\hline & $\begin{array}{r}\text { Total Var } \\
\text { KMOrtlett's Test of Spl }\end{array}$ & $\begin{array}{r}51,393 \\
0,824 \\
54,867 \\
\text { Sd: } 6 \\
0,000\end{array}$ \\
\hline
\end{tabular}

Result of the factor analysis determined that there are 3 dimensions regarding work alienation and 3 dimensions regarding organizational justice. Total variance of work alienation factors (self-alienation, powerlessness, meaninglessness) is 55,325\%; total variance of organizational justice factor (distributive justice, procedural justice and interactional justice) was $66,147 \%$. Mean values, standard deviation and correlations regarding Organizational Justice, Work Alienation and Person-Organization Fit were studied and given in Table 6.

Table 6: Mean Values, Standard Deviation, Correlation Values and Reliabilities of Scales Regarding Research Variables

\begin{tabular}{|c|c|c|c|c|c|c|c|c|c|}
\hline Variables & $\begin{array}{l}\text { Mea } \\
\text { n V. }\end{array}$ & $\begin{array}{l}\text { St. } \\
\text { Dev. }\end{array}$ & 1 & 2 & 3 & 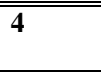 & 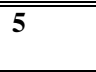 & 6 & 7 \\
\hline $\begin{array}{l}\text { 1.Distributi } \\
\text { ve Justice }\end{array}$ & 2,963 & (9379 & $(0,769)$ & & & & & & \\
\hline $\begin{array}{l}\text { 2.Interactio } \\
\text { nal Justice }\end{array}$ & 3,252 & ,9056 &, $560 * *$ & $\begin{array}{l}(0,943 \\
)\end{array}$ & & & & & \\
\hline $\begin{array}{l}\text { 3.Procedura } \\
1 \text { Justice }\end{array}$ & 3,314 & ,8031 &, $466^{* *}$ &, $625 * *$ & )$^{(0,744}$ & & & & \\
\hline $\begin{array}{l}\text { 4.Powerless } \\
\text { ness }\end{array}$ & 3,771 & ,8570 &,- 159 &,$- 221^{*}$ &,- 028 & $(0,674)$ & & & \\
\hline $\begin{array}{l}\text { 5.Self- } \\
\text { Alienation }\end{array}$ & 2,784 & ,8890 & , $257 * *$ & , $273 * *$ &,- 080 &,$-377 * *$ & $\begin{array}{l}(0,789 \\
)\end{array}$ & & \\
\hline $\begin{array}{l}\text { 6.Meaningl } \\
\text { ess }\end{array}$ & 2,343 & ,8082 & ,273** & , $332 * *$ &,$- 237 *$ & ,193* & $465 * *$ & )$^{(0,843}$ & \\
\hline $\begin{array}{l}\text { 7.Person- } \\
\text { Organizatio } \\
\text { n Fit }\end{array}$ & 3,485 & 1,004 &, $474 * *$ &, $640 * *$ &, $465 * *$ &,$- 380 * *$ & , $499^{* *}$ &,$- 535^{*}$ & $\begin{array}{l}(0,922 \\
)^{2}\end{array}$ \\
\hline
\end{tabular}

Table-6 also shows that there were significant relationships between all dependent and independent variables studied in this research. For this reason, each variable affect others significantly. It was determined that the mean values of these variables varied between 2,7840 and 3,771 and Cronbach Alpha inner reliability coefficients of all variables were above $67 \%$. The correlation values between the variables were as follows. Correlation between distributive justice and self- alienation $(r=-.257 ; \mathrm{p}<.01)$ was negative, and the correlation between distributive justice and person-organization fit $(\mathrm{r}=.474 ; \mathrm{p}<.01)$ was positive. There was a medium-level relationship between those. Correlation between interactional justice and meaningless $(r=-.332 ; p<.01)$ was negative and correlation between interactional justice and person-organization fit $(\mathrm{r}=.640 ; \mathrm{p}<.01)$ was positive. Correlation between procedural justice and meaningless $(\mathrm{r}=-, 237 ; \mathrm{p}<.05)$ was negative and correlation between procedural justice and person-organization fit $(\mathrm{r}=.465 ; \mathrm{p}<.01)$ was positive.

Three regression analyzes were conducted to test the effect of organizational justice on work alienation (Table 7). Stepwise method was used in regression analysis. 
Table 7: Regression Analysis of Research Variables

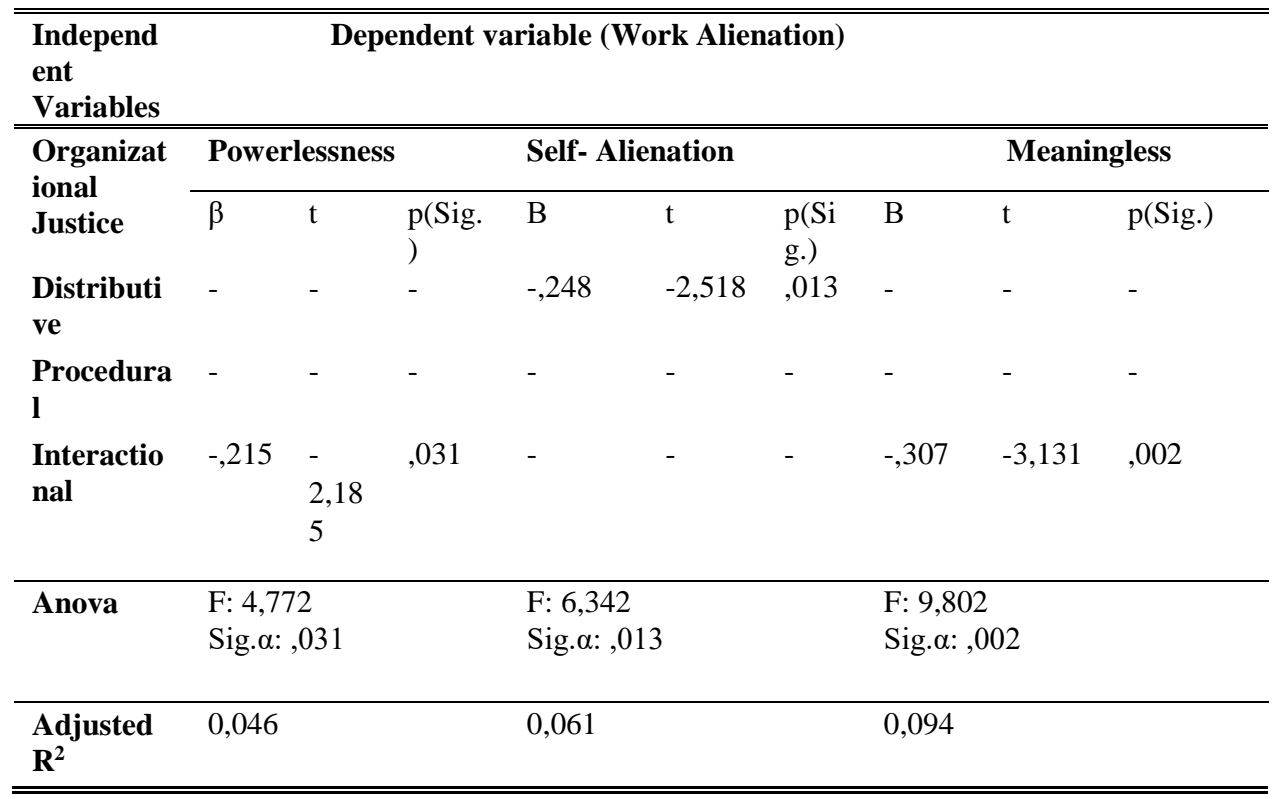

According the Table-7 that the organizational justice had significantly predicted the powerlessness dimension (4,6\%), which was the work-alienation sub-dimension (F:4,772; p:0,031). In addition, the organizational justice subdimension, distributive justice had significantly predicted the self-alienation dimension $(6,1 \%)$, which is the work-alienation sub-dimension (F:6,342; p:0,013). Also, the organizational justice subdimension, interactional justice has significantly predicted the meaningless dimension $(9,4 \%)$, which is the work alienation sub-dimension (F:9,802; p:0,002).

Finally; The interactional justice affects the powerlessness dimension in the negative direction $(\beta$ : -,215 p:0,031). Distributive justice has negative effect on self-alienation ( $\beta:-, 248, \mathrm{p}:, 013)$, interactional justice affects the meaningless negatively $(\beta:-, 307, \mathrm{p}:, 002)$. So $\mathrm{H}_{1}$ and $\mathrm{H}_{2}$ hypothesis are partly supported.

As a part of the analysis collinearity was considered to identify a potential multicollinearity problem. Tolerance and VIF values that were obtained in the analyses confirmed there isn't multicollinearity between independent variables.

To explain the role of Person-Organization Fit on Organizational Justice's Effect on Work Alienation four pre-requisites proposed by Baron ve Kenny (1986) were implemented. There pre-requisites are listed as finding statistically significant correlations between Organizational Justice (independent variable) and Work Alienation (dependent variable); Organizational Justice (independent) and Person-Organization Fit (dependent);PersonOrganization Fit (intermediary fit) and Work Alienation (dependent). Sobel test was employed to identify the significance of mediation effect.

To test the mediation effect (agency) of Person-Organization Fit in the correlation between Organizational Justice and Work Alienation a three step multi linear regression analyses was used (Table-8). First the mediation effect of Person-Organization Fit on distributive justice aspect of the organizational justice and work alienation was determined. 
Table 8: Regression Analysis of Research Variables

\begin{tabular}{|c|c|c|c|c|c|c|c|}
\hline & $\begin{array}{l}\text { Dependen } \\
\text { t Variable }\end{array}$ & $\begin{array}{l}\text { Independent } \\
\text { Variable }\end{array}$ & $\begin{array}{l}\text { Beta } \\
\text { Unstn }\end{array}$ & $\begin{array}{l}\text { Std. } \\
\text { Error }\end{array}$ & $\begin{array}{l}\text { Beta } \\
\text { Stand }\end{array}$ & p & $\mathbf{R}^{2}$ \\
\hline Step 1 & $\begin{array}{l}\text { Work } \\
\text { Alienation }\end{array}$ & $\begin{array}{l}\text { Organization } \\
\text { al Justice }\end{array}$ & & & & & \\
\hline Constant & & & 3,825 & ,253 & & & \\
\hline Organizati & nal Justice & &,- 336 & 077 &,- 388 & ,000 & , 151 \\
\hline Step 2 & $\begin{array}{l}\text { Person- } \\
\text { Org. Fit }\end{array}$ & $\begin{array}{l}\text { Organization } \\
\text { al Justice }\end{array}$ & & & & & \\
\hline Constant & & & ,664 & ,311 & & & ,428 \\
\hline Organizati & nal Justice & & 879 & ,094 & ,654 & ,000 & \\
\hline Steps 3-4 & $\begin{array}{l}\text { Work } \\
\text { Alienation }\end{array}$ & $\begin{array}{l}\text { Organization } \\
\text { al Justice } \\
\text { Person-Org. } \\
\text { Fit }\end{array}$ & & & & & \\
\hline \multirow{3}{*}{\multicolumn{3}{|c|}{$\begin{array}{l}\text { Constant } \\
\text { Organizational Justice } \\
\text { Person-Org. Fit }\end{array}$}} & 4,079 & ,219 & & ,000 & \\
\hline & & &, 061 & 084 & ,071 & 472 & \\
\hline & & &,- 441 & ,064 &,- 679 & ,000 & , 405 \\
\hline
\end{tabular}

According to multi linear regression analysis, regression equality as is follows.

1. Work Alienation $=3,825-0,388$ Organizational justice

2. Person-Organization Fit $=0,664+0,654$ Organizational justice

3. Work Alienation $=4,079+0,071$ Organizational justice - 0,679 Person-Organization Fit

Figure 2

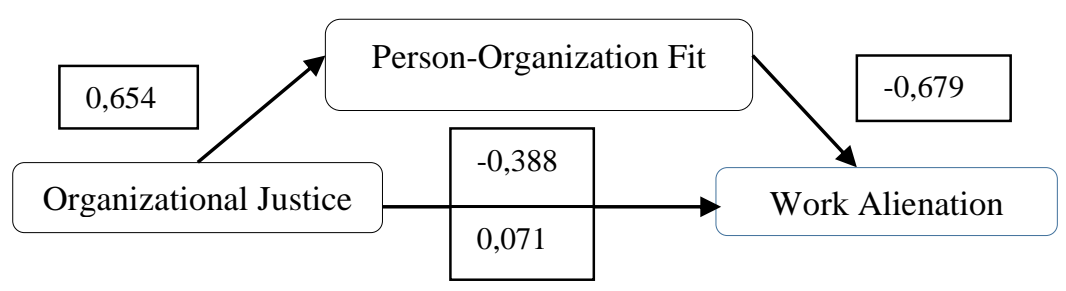

According to the results of multiple linear regression analysis, organizational justice has a negative effect on work alienation $(\beta=-0.388, \mathrm{p}: 0,000)$. In this context, as organizational justice increases, work alienation will decrease. Organizational justice has a positive and statistically significant effect on person organization fit $(\beta=0,654, p: 0,000)$. In addition, person-organization fit has a negative effect on work alienation $(\beta=-0.679$, p:0,000). When the effect of person-organization fit (mediating effect) is checked, it is observed that the beta value decreases from -0.388 to 0,071 and the effect of organizational justice on work alienation becomes statistically insignificant (figure-2). In order to test the significance of this decrease, the $\mathrm{z}$ value calculated by the Sobel test was measured and the $\mathrm{z}$ value was 5.54 ( $\mathrm{p}<0.05$ ). Statistical significance of $\mathrm{z}$ indicates that the $\mathrm{H}_{3}$ hypothesis is supported. The significance in the change of beta values was tested using Sobel test statistics that are available online (Preacher ve Leonardelli, 2016). It was found that there was a mediating role of person-organization fit on the effect of organizational justice perception and work alienation levels.

\section{Conclusion}

Throughout history, the state of justice was established and maintained by the rules that regulate communal living. Individuals reacted to unjust practices with vocally and non-vocally. However today, when individuals working together faced unjust practices, decision or behavior in organizations, they may simply choose to not react or neglect their work for the fear of losing their employment. This may lead to an individual losing his commitment to work, and increase in work alienation. Consequently, performance of the human factor which is very important for organizations decreases. This in turn effects the organizations negatively.

In the light of the data it can be said that there is a positive medium/low level correlations between the research variables. Moreover, regression models determined that organizational justice perceptions have statistically significant positive correlation with person-organization fit and a statistically significant negative 


\section{Uluslararası Yönetim İktisat ve İşletme Dergisi, ICMEB17 Özel Sayısı \\ Int. Journal of Management Economics and Business, ICMEB17 Special Issue}

correlation with work alienation. It was also determined that person-organization fit had a negative effect work on work alienation.

According to the analysis of the regression model with distributive justice and interactional justice each independent and mediating variable had a statistically significant correlation with work alienation $(\mathrm{F}=34,769$, $\mathrm{p}<.001 ; \mathrm{F}=14,146, \mathrm{p}<.001) .40,3 \%$ of work alienation can be explained using distributive justice, and $12,6 \%$ of work alienation can be explained using interactional justice $\left(\mathrm{R}^{2}=.403\right)$. Based on that it can be said that personorganization fit has a full agency (mediation effect) on the effect of distributive and interactional justice on work alienation.

In the last regression model effects of procedural justice was studied along with theoretically independent variables and the mediating variables (person-organization fit) on work alienation has been studied. According to that analysis each independent and mediating variable has a statistically significant $(F=39,650, p<.005)$ effect on work alienation. $21,6 \%$ of the change in work alienation can be explained with these variables $\left(\mathrm{R}^{2}=.216\right)$. Thus, it can be said that person-organization fit has a partial mediation effect on the effect of procedural justice on work alienation.

The interactional justice affects the powerlessness dimension in the negative direction $(\beta:-, 215 \mathrm{p}: 0,031)$. Interactional justice affects the meaningless negatively $(\beta:-, 307, \mathrm{p}:, 002)$. The decisions transferred to employees in an honest, respect and courtesy manner by the managers will help the employees feel that they are important for the organization, and feel that they are adequate in their jobs. The interaction injustice causes the individual to feel unimportant, unable to realize who they are as an individual. Powerlessness is the perception that employees are just as valuable as the contributions they provide for the organization. Moreover, the fact that the managers do not give any explanation or information to employees may destroy the feeling of ownership of the work and may cause the occupation to be out of control. In this sense, if the interaction justice in the organization increases, the selfconfidence of the occupants arises and the employees have more commitment for the work. Employees also use their talents and abilities on their jobs, and see the importance of their efforts to achieve their organizational goals. Thus making sense to their work. Interaction justice makes the work meaningful. Distributive justice has negative effect on self-alienation ( $\beta$ :-,248, p: ,013). All kinds of gains such as wages, awards, careers, and punishments are perceived fairly by employees can reduce levels of self-alienation.

According to the results of multiple linear regression analysis, organizational justice has a negative effect on work alienation $(\beta=-0.388, \mathrm{p}: 0,000)$. In this context, as organizational justice increases, work alienation will decrease. Organizational justice has a positive and statistically significant effect on person organization fit $(\beta=0,654, p: 0,000)$. In addition, person-organization fit has a negative effect on work alienation $(\beta=-0.679$, p:0,000). Results of this study demonstrate that organizational justice indirectly effects work alienation. That is to say that person-organization is a mediating variable on the effect of organizational justice on work alienation. As organizational justice increases in an organization, person-organization fit increases and consequently as personorganization fit increases work alienation decreases.

According to the results of the study, managers in organizations should value their employees and inform them about the decisions. The perception that employees try to achieve someone else's goals can cause employees to reduce autonomy and control over their work. The job involvement of employees and struggling as if they had their own business will contribute to carry out the organizational goals.

\section{References}

Aiken, M. \& Hage, J. (1966). Organizational alienation: A comparative analysis. American Sociological Review, 497-507.

Altaş, S. S., \& Çekmecelioğlu, H. G. (2015). Örgütsel adalet algısının iş tatmini, örgütsel bağlilik ve iş performansi üzerindeki etkileri: Okul öncesi öğretmenleri üzerinde araştirma. Ataturk University Journal of Economics \& Administrative Sciences, 29(3), 421-439.

Baron, R. M., \& Kenny, D. A. (1986). The moderator-mediator variable distinction in social psychological research: Conceptual, strategic, and statistical considerations. Journal of Personality and Social Psychology, 51(6), 1173.

Bonjean, C. M., \& Grimes, M. D. (1970). Bureaucracy and alienation: A dimensional approach. Social Forces, 48(3), 365-373.

Ceylan, A., \& Sulu, S. (2011). Organizational injustice and work alienation. E+M Ekonomie a Management, 2 , 65-78.

Chatman, J. A. (1991). Matching people and organizations: Selection and socialization in public accounting firms. Administrative Science Quarterly, 36(1), 459-484.

Colquitt, J. A. (2001). On the dimensionality of organizational justice: A construct validation of a measure. Journal of Applied Psychology, 86(3), 386. 
Cowherd, D. M., \& Levine, D. I. (1992). Product quality and pay equity between lower-level employees and top management: An investigation of distributive justice theory. Administrative Science Quarterly, 302-320.

Cropanzana, R., Bowen, D. E. \& Gilliland, S. W. (2007). The management of organizational justice. The Academy of Management Perspectives, 34-48.

Cropanzano, R., Byrne, Z. S., Bobocel, D. R., \& Rupp, D. E. (2001). Moral virtues, fairness heuristics, social entities, and other denizens of organizational justice. Journal of vocational behavior, 58(2), 164-209.

Erben, G. S. (2008). Effects of perceived employment opportunities, peer support, exhaustion and work alienation on the relationship between perceived job characteristics and a comparative study between lean and traditional production contexts (Doktora tezi), Marmara Üniversitesi, İstanbul.

Folger, R. G., \& Cropanzano, R. (1998) Organizational justice and human resource management. Sage Publications, 7.

Greenberg, J. (1987). A taxonomy of organizational justice theories. Academy of Management Review, 12(1), 922.

Greenberg, J. (1989). Cognitive reevaluation of outcomes in response to underpayment inequity. Academy of management journal, 32(1), 174-184.

Greenberg, J. (1990). Organizational justice: Yesterday, today, and tomorrow. Journal of management, 16(2), 399432.

Günsal, E. (2010). Algllanan örgütsel adalet ile örgütsel yabancılaşma arasında bir ilişki ve bir araştırma. (Yüksek Lisans Tezi), Marmara Üniversitesi, İstanbul.

İşcan, Ö. F., \& Sayın, U. (2010). Örgütsel adalet, iş tatmini ve örgütsel güven arasindaki ilişki. Atatürk Üniversitesi Iktisadi ve Ídari Bilimler Dergisi, 24(4).

Kanten, P., \& Ülker, F. (2014). Yönetim tarzinin üretkenlik karşiti iş davranişlarina etkisinde işe yabancilaşmanin aracilik rolü. Mugla Sitki Kocman University Journal of Social Sciences, 32.

Kurtulmus, M. \& Karabiyik, H. (2016). Algilanan örgütsel adaletin ögretmenlerin ise yabancilasma düzeylerine etkisi / The effect of perceived organizational justice to work alienation level. Bartin Üniversitesi Egitim Fakültesi Dergisi, 5(2), 459.

Moon, H., Kamdar, D., Mayer, D. M. \& Takeuchi, R. (2008). Me or we? The role of personality and justice as other-centered antecedents to innovative citizenship behaviors within organizations. Journal of Applied Psychology, 93(1), 84.

Mottaz, C. J., 1981, Some Determinants of Work Alienation. The Sociological Quarterly, 22(4), 515-529.

Nadiri, H. \& Tanova, C. (2010). An investigation of the role of justice in turnover intentions, job satisfaction, and organizational citizenship behavior in hospitality industry. International journal of hospitality management, 29(1), 33-41.

Netemeyer, R. G., Boles, J. S., McKee, D. O. \& McMurrian, R. (1997). An investigation into the antecedents of organizational citizenship behaviors in a personal selling context. Journal of Marketing, 85-98.

Ölçer, F. (2015). The investigation of the relationship between organizational justice and turnover intention: The mediating role of organizational commitment. Economic Computation \& Economic Cybernetics Studies \& Research, 49(3).

Özçelik, K. (2011). Kişi örgüt uyumu ve etik iklimin hastaneye bağlllı̆̆a etkisi: Hemşireler üzerinde bir araştırma. (Yüksek Lisans Yüksek Lisans), Beykent Üniversitesi, Istanbul.

Polatçı, S., \& Cindiloğlu, M. (2013). Kişi-örgüt uyumunun örgütsel vatandaşlık davranışına etkisi: Duygusal bağlılığın aracılık rolü. Süleyman Demirel Üniversitesi İktisadi ve İdari Bilimler Fakültesi Dergisi, 18(3), 299-318.

Polatçı, S. \& Özçalık, F. (2015). Çalışanların örgütsel adalet algıları ile üretkenlik karşıtı iş davranışları etkileşiminde pozitif ve negatif duygusallığın aracılık etkisi. Dokuz Eylül Üniversitesi Sosyal Bilimler Enstitüsü Dergisi, 17(2), 215-234.

Sayü, P. (2014). The relationship between organizational justice and work alienation. (Yüksek Lisans Tezi), Marmara Üniversitesi, İstanbul.

Şimşek, M. Ş., Çelik, A., Akgemci, T. \& Fettahoğlu, T. (2006). Örgütlerde yabancilaşmanin yönetimi araştirmasi. Selçuk Üniversitesi Sosyal Bilimler Enstitüsü Dergisi, 15, 569-587.

Şirin, E. F. (2009). Beden eğitimi öğretmenlerinin işe yabancılaşma düzeylerinin bazı değişkenler açısından incelenmesi. CBÜ Beden Eğitimi ve Spor Bilimleri Dergisi, 4(4), 164-177.

Taştan, S., İşci, E. \& Arslan, B. (2014). Örgütsel destek algisinin işe yabancilaşma ve örgütsel bağliliğa etkisinin incelenmesi: İstanbul özel hastanelerinde bir çalişma. Pamukkale Üniversitesi Sosyal Bilimler Enstitüsü Dergisi, 19, 121-138.

Topakkaya, A. (2008). Adalet kavramı bağlamında Aristoteles-Platon karşılaştırması. SDÜ Felsefe Bilimler Dergisi, 6, 27-49.

Turgut, T. \& Kalafatoğlu, Y. (2016). İşe yabancilaşma ve örgütsel adalet. "İ̧̧, GÜÇ" Endüstri İlişkileri ve Insan Kaynaklarl Dergisi, 18(1), 23-46. 
Turunç, Ö. \& Çelik, M. (2012). İş tatmini-kişi-örgüt uyumu ve amire güven-kişi-örgüt uyumu ilişkisinde dağitim adaletinin düzenleyici rolü. $\dot{I}_{\text {ş, }}$ Gü̧, Endüstri İlişkileri ve İnsan Kaynakları Dergisi, 14(2), 57-78.

Yahyagil, M. Y. (2005). Birey ve organizasyon uyumu ve çalişanlarin iş tutumlarina etkisi. Marmara Üniversitesi Öneri Dergisi, 24, 137-149.

Yürür, S. (2008). Örgütsel adalet ile iş tatmini ve çalışanların bireysel özellikleri arasındaki ilişkilerin analizine yönelik bir araştırma. Süleyman Demirel Üniversitesi İktisadi ve İdari Bilimler Fakültesi Dergisi, 13(2). 